\title{
Study on College English Teachers ESP Teaching Transformation
}

\author{
Junhua Zhou \\ Junhua Zhou,Weifang University of Science and Technology,262700
}

\begin{abstract}
With the deepening of the reform of College English Teaching, ESP teaching has been widespread concerned in society. How to successfully transform form EGP teachers into ESP teachers is a new challengein the field of education.
\end{abstract}

KEYWORDS:EGP; ESP; Public English Teacher; Transformation

\section{Introduction}

English for specific purposes (ESP) refers to a practical way of teaching English based on professional needs, including business English, scientific English, legal English, etc.With respect to the English for general purposes (EGP), ESP is of stronger relevance and practicality, thus more directly meets the needs of society. With the growing internationalization of economic and cultural development, the demand for compound talents who master both professional skills and fluent English is increasing. Currently, traditional English teaching form has been difficult to train appropriate practical English talents, so it requires colleges and universities shift the focus of English teaching to ESP teaching, combining the professional knowledge with English ability training, to cultivate students' professional English proficiency. At the same time, some EGP teachers are facing the mission of transition to ESP teachers. In this context, How to promote a smooth transition to ESP teachers from ESP teachers has become a very important research topic in the field of education.

\section{ESP Teaching Status}

Currently, ESP curriculum has become the main courses of English teaching in international universities. In countries of high popularity degree of English, ESP is generally taking as the only English language course in colleges, and only a small part of students of the weak English foundation will select EGP courses. In Japanese universities, there is not only ESP research center, but also regularly hold related symposium.

Because of the late start and lack of advanced theoretical guidance, ESP teaching development always remains stagnant in our country. First, most of our colleges and universities attach weak importance to the ESP course. Educators have a greater divergence of whether college English teaching should focus on laying the foundation or training academic skills. Second, introduction of ESP courses is quite late,just copying the ESP teaching mode abroad, lack of advanced theoretical guidance. English teachers generally use grammar explanations plus translation teaching method, simply translating paragraph or sentence into Chinese. Third, quality of ESP Teaching materials is not high.In order to combine the ESP curriculum with various professionals, colleges and universities 
lack of certain specification in the selection of the ESP teaching material. Finally, Due to the differences of Teachers, ESP course teachers is weak. Currently, the vast majority of colleges and universities haven't set up dedicated ESP teachers, but generally hold a concurrent post by college English teachers, so it cannot guarantee a good quality of teaching requirements.

From the perspective of teachers, because training model of ESP teacher is different from EGP teachers, role conversion of English teachers often has some limitations. On the one hand, EGP teachers do not master sufficient professional principles, professional terminology and professional routine, therefore they are often confined to the explanation of textbook itself and translation of sentence, difficult to expand and extend the professional knowledge. On the other hand, EGP teachers generally only need to assume the role of language teaching, while ESP teachers need to assume more roles and responsibilities of manager, assessor and researcher. ESP teachers must have higher comprehensive quality, for they should participate in curriculum design, textbook compilation, teaching evaluation, etc. In addition, the new cultivation mode requires ESP teachers to pay more attention to their own development. However, they are often busy in teaching first-line, lack of sufficient time and energy for self-learning. Therefore, ESP teachers are supposed to explore the new learning channel and learning methods, to adapt to the requirements of new teacher training mode.

\section{Inevitable Trend of Transformation}

\section{A. Demand from Students}

Survey showed that, more than eighty percent of non-English major students thought they have the interests and needs to accept ESP learning, and believed it think can help them gain an edge in the job. As for how to better learn ESP courses, the respondents considered own effort, the instructor and teaching resources are the most important factors. To conduct ESP teaching can improve students' English ability in the professional field or specific jobs, affecting students' future career and personal development. Therefore, from the perspective of the students themselves, it is necessary to pay attention to ESP teacher training and ESP courses.

\section{B. Weak ESP Faculty}

At present, China ESP local colleges teaching faculty are divided into two categories: one is common English teachers; the other is professional course teachers with a certain level of English. Although professional course teachers master a good knowledge in the professional field, they generally lack of theory and experience of language courses teaching. They often simply translate professional vocabulary in class, so students find it difficult to get the correct language learning skills. On the other hand, public English teachers have more solid English foundation and rich language teaching experience, but their professional knowledge structure is weak. ESP Teaching positioning belongs to the category of language teaching, so it Need to follow the rules and theories of language teaching. Therefore in contrast, after upgrading their professional knowledge, public English teachers are more suited to undertake ESP teaching work than professional course teachers.

\section{English Teaching Reform}

For many years in the past, thanks to the popularity of English teaching in basic compulsory, English ability of primary and 
secondary school students in our country has obvious improvement. Education scholars think that, English teaching in the new era should combine more with professional knowledge, taking ESP teaching as the focus of college English teaching. English Teaching in Higher Vocational Education Requirements introduced in 2000 indicated that should focus on cultivation of students practice English skills, which requires colleges and universities to teach English in a simulated workplace environment, that is, ESP curriculums. Yet English teacher is the key to carry out the ESP course, so transformation of college EGP teachers into ESP teachers a response to the need for college English teaching reform.

Generally speaking, with the continuous reform and development of college English teaching, more and more colleges begin to decrease EGP courses and increase ESP course, for transformation of EGP teachers to ESP teachers is an inevitable trend.

\section{Transformation Strategies}

\section{A. Formulate Favorable Policy}

Colleges should develop a scientific and rational policy, and pay more attention to the reform of ESP courses and ESP teacher development. Colleges should focus on cultivate the social talents who can achieve long-term development. Today's society is more and more internationalized, thus Professional English Teachingis playing a decisive role. Whether EGP teachers are able to transform into ESP teachers, has an important influence on ESP teaching. Colleges should formulate should related policies, on the one hand, to provide economic support for ESP transformation; on the other hand, to provide ESP teachers with the greatest possible autonomy and flexibility in terms of course arrangement, teaching plan and teaching mode, etc. Managers should actively listen to the views and suggestions of ESP teachers, and encourage various forms of innovation, to promote deepening reform of ESP courses. Moreover, state education departments should establish and improve the ESP teacher evaluation mechanism, and standard ESP teacher certification, to comprehensive evaluate ESP teachers' teaching level. It not only helps develop teachers group, but also improve business and theoretical level of ESP teachers.

\section{B. Establish Long-term Training Mechanism}

As mentioned above, ESP teaching usually has two requirements: one is solid English skills; the other is rich professional knowledge. In order to better undertake ESP teaching, ESP teachers need to learn and improve for a long term, so ESP teacher training is particularly important. Education department or other related social departments should establish a long-term and effective mechanism of the training, providing the systematic training of professional knowledge and teaching skills. In recent years, Training of English teachers in Colleges and universities have achieved big improvement, but it is still mainly the form of Short-term Theory Teaching, lack of Strong support for the long-term training mechanism.

Despite the short-term teaching practice and theoretical study have some positive effects on English teachers training, to guarantee an EGP teacher truly transform into ESP teacher, several short-time training is hard to work. In the long-term needs of practice teaching, it needs to be constantly peppered with all kinds of special training, to make the training concepts combined with teaching practice and be improved. Therefore, only by establishing a 
long-term mechanism of ESP teacher training can better promote transformation of EGP teachers into ESP teachers.

\section{Rightly Self-positioning and Learning}

Firstly, teachers should be ready for transition in ideologically and psychologically, and then according to the characteristics and advantages of their own, determine the direction of the transformation. Teachers should accurately position themselves as soon as possible, and actively accept the new teaching model instead of the old teaching ideas. ESP teachers should take the initiative to learn, so as to make up for their lack of expertise in the structure, increasing the "hardware chips" for role reversal. ESP teachers should seize the opportunity to conduct professional training of school extracurricular learning, or make use of advanced studies or enterprise testing exercise to improve the level of professional knowledge and practical skills.

In addition, ESP teachers should take initiative to establish exchanges and cooperation with professional teachers, to learn the learning channels and learning skills of professional knowledge from them. Only the correct self-localization and active self-learning can make themselves successfully transform from EGP teachers to qualified ESP teachers.

\section{Develop Co-teaching Mode}

Since the EGP teachers and professional teachers are respectively provided with language teaching experience and professional knowledge teaching experience, in order to make full use of the advantage of the two groups of teachers, colleges can develop co-teaching mode by them, and establish the dual training mode of ESP teachers. ESP teachers dual training mode is to take ESP curriculum jointly development and curriculum design activities as the carriers, to bidirectionally train and enhance teaching and research capabilities of ESP teachers.

\section{CONCLUSIONS}

Such teaching team of co-teaching nature is aiming at ESP courses construction, by absorb a number of English teachers who are interested in professional knowledge and professional teachers who have good English ability, to build a pluralistic-structure teaching team that there was a gradient in the teaching and research experience. The teaching team activities mainly include: starting from the students demand research, to conduct syllabus design, teaching materials preparation, teaching resource allocation, teaching activities organization and teaching effectiveness assessment, etc. When allocate the teaching task, should carry out rational division according to the advantage of two types of teachers. EGP teachers are responsible for development of teaching methods, guidance of language skills and textbooks structure design; while professional teachers are responsible for construction of expertise framework, course objectives setting and course content arrangement. By the mode of mutual cooperation and common teaching, the teachers learn from each other, which is in favor of ESP teacher training and skills upgrading.

\section{REFERENCE:}

[1] Hutchinson, T \& Waters, A. English for specific purposes $[\mathrm{M}]$. Cambridge: Cambridge University Press, 1987.

[2] Dudley-Evans T, St John M J. Developments in English for specific purposes: A multi-disciplinary approach[M]. Cambridge university press, 1998.

[3] Romo J J, Chavez C. Border pedagogy: A study of preservice teacher transformation[C]//The 
Educational Forum. Taylor \& Francis Group, 2006, 70(2): 142-153.

[4] Jigang C. ESP and the direction of China's college English teaching $[\mathrm{J}]$. Foreign Language World, 2004, 2: 003.

[5] Far M M. On the relationship between ESP \& EGP: A general perspective[J]. English for Specific Purposes World, 2008, 7(1): 1-11.
[6] Fang Y. Discussion on university English EGP+ ESP mode in independent college[J]. Journal of Jiamusi Education Institute, 2012, 5: 261.

[7] Wei L. Integration of ESP into EGP: The Multidimensional and Hybrid English Training Model in Liaoning Police Academy[J]. Theory and Practice in Language Studies, 2012, 2(9): 1877-1884. 